\title{
Is Hunger Destined to be Perpetual in Burundi?
}

\author{
Lincoln J. Fry ${ }^{1 *}$ \\ ${ }^{1}$ Academic Member, Sociology Research Unit, Athens Institute for Education and Research (ATINER), \\ Athens, Greece \\ *Lincoln J. Fry, E-mail: lincolnfry@ bellsouth.net
}

Received: February 21, 2017

Accepted: March 5, 2017

Online Published: March 15, 2017

doi:10.22158/fsns.v1n1p11

URL: http://dx.doi.org/10.22158/fsns.v1n1p11

\begin{abstract}
Hunger is a worldwide problem, and Africa is the continent with the world's highest percentage of hungry persons; Burundi is Africa's hungriest country. This paper addresses hunger in Burundi and then identifies the factors that predict hunger in that country. Burundi is a rural country and its rural population will receive a great deal of attention in this paper, especially because the study looks closely at literature's suggestion that farmers may be hungrier than the rest of the population, and gender may be a factor. This study is based on a national probability sample of 1,200 Burundi respondents included in Round 6 of the Afrobarometer survey conducted in 2014. The search is for policy related factors that would help alleviate Burundi's hunger problem. To preview the findings, this study did not find any light at the end of the tunnel. The factors that predicted hunger were primarily immutable indicators, education, agriculture as an occupation, and wealth, as measured by assets owned. Over 80 percent of the respondents felt the government was not ensuring that people had enough to eat. Eighty-seven percent were unemployed, 86 percent were rural residents and 71 percent of the respondents reported some degree of hunger, about one-fourth reported being hungry all of the time. The gender and hunger relationship was significant at the bivariate level, but that relationship disappeared in the ordered logistical analysis.
\end{abstract}

\section{Keywords}

Burundi, hunger, rural, agriculture, farmers

\section{Introduction}

In 2014, Burundi topped the Global Hunger Index for the third year in a row. The country has been described as one of the least developed countries (Jenicek \& Grofova, 2015) and the hungriest, not only in Africa, but in the world (Africaranking.com, 2015). A landlocked country in the African Great Lakes region, it is bordered by Rwanda, Tanzania and the Democratic Republic of the Congo. Two civil wars and genocides during the 1970s and again in the 1990s have left this predominantly rural country not only undeveloped and its population of roughly 10.5 million, one of the poorest in the world. 
Against that backdrop, this paper assesses the extent of self-reported hunger among 1,200 Burundi respondents and then searches for the factors that predict hunger in that country. Even though Burundi has been somewhat neglected, the literature devoted to what is commonly called food insecurity will be reviewed. Some of the issues raised in the African food insecurities literature will be addressed and are questions central to this paper's analysis. These include whether rural residents, especially agricultural workers, are hungrier than other Burundi respondents. Other topics include whether gender differences in hunger are apparent, and are there any implications in this research that add any knowledge about hidden hunger? As the title of the paper suggests, the big question will be is there any light at the end of the tunnel regarding hunger in Burundi?

\subsection{Hunger in the World and Africa}

According to the WHES (World Hunger Education Service) World Hunger and Poverty Facts and Statistics Report (2015), hunger has three meanings. Two of those meanings deal with craving or desire for food. The third meaning refers to the want or scarcity of food in a country, and it is in this sense that this paper addresses hunger. There are two classifications of hungry persons that are of interest here. The broadest classification includes those who suffer from what is known as "hidden hunger". These are an estimated two billion persons that are affected by a chronic deficiency of essential vitamins and minerals. Among this population the signs of malnutrition and hunger are less visible, but it has negative and long term consequences, often for long term health, productivity and cognitive development (Muthayya et al., 2013). The second classification includes those who demonstrate clear cut hunger; in the latest UN Food and Agriculture Organization Report (2015), the estimate was that 925 million people were hungry worldwide, and that 239 million people in sub-Saharan Africa were hungry or undernourished. This made Africa the continent with the second largest number of hungry people, following Asia and the Pacific with 578 million. Due to the difference in population sizes, Sub-Saharan Africa actually had the largest proportion of hungry/undernourished people, estimated at 30 percent of the population compared to 16 percent for Asia and the Pacific.

\subsection{Food Insecurity in Sub-Saharan Africa}

As Clover (2003) has suggested, despite the fact that the right to food is one of the most consistently acclaimed rights in international human rights law, no other human right has been so frequently and spectacularly violated. Clover's discussion of food insecurity in Sub-Saharan Africa leads to the conclusion that hunger is a multi-faceted issue in Africa, and that just growing more food will not eradicate the problem. Agriculture is important and Clover points out that Africa has gone from being a key agricultural commodity exporter into being a net importer; the African continent now receives the most food aid. Perhaps the most important point Clover made was to suggest hunger will not be eradicated by just throwing money at the problem. Hunger is a political creation which must be ended by political means, a theme which will be mentioned below and revisited in the Discussion section.

\subsection{Hunger in Burundi}

Malnutrition is the $4^{\text {th }}$ leading cause of death in Burundi, and the $3^{\text {rd }}$ leading cause of total deaths in the 
country. The country ranks $6^{\text {th }}$ in the world in this category (worldlifeexpectancy.com, 2016), with over $60 \%$ of the country's population deemed undernourished. According to Jenicek and Grofova (2015) they classify Burundi as the world's third poorest country, a country that is highly vulnerable to natural disasters which contribute further to nutritional instability. Burundi has been afflicted by a wide range of challenges such as land shortage, land degradation, corruption, increased political instability and ethnic civil unrest (especially since 1990), and, HIV/AIDS. According to Fauk et al. (2017), there are 610,000 children in Burundi who are orphans. Most because of AIDS, but many have been abandoned by their parents because of their dire economic situation. To make matters worse, even those with intact families are faced with poor access to education, which means that the country's youth is challenged in the task of bringing about significant development in the near future.

Burundi is a rural country and its economy is based on agriculture. As Jenicek and Grofova (2015) noted, as of 2007, 90 percent of Burundi's population lived in rural areas. Food crops occupy 85 percent of agricultural land and most crops are produced for the owner's consumption. There is a shortage of agricultural land and there has been a fourfold increase in population and land holdings have been divided to accommodate the claims of sons for family land. The return of nearly 500.000 refugees has increased the pressure on land ownership. The UN started intervening in 1993-first through efforts at peace-keeping, and then through reconstruction projects. Today, $42 \%$ of Burundi's national income is from foreign aid.

\subsection{Hunger and Farmers, Climate Change, and Gender}

As Sanchez and Swaminathan (2005) indicated, roughly half, 50\%, of the hungry are found in small holder farming households. Another $20 \%$ are the landless rural and $10 \%$ are pastoralists, fishers and forest dwellers; the remaining 20 percent are urban residents. This paper will look at farmers, in order to determine if they are in fact hungrier than other Burundi respondents. There are several issues that emerge from the rural hunger literature. The first is climate change Shisanya and Mafongoya (2016) who suggested that smallholder subsistence farmers will face severe negative impacts from climate change, with their household food security being seriously affected. This paper examines the extent to which farmers see climate change as an issue the government should address. The final issue addressed here is the way gender affects hunger in Burundi, especially female farmers. As Abebayo and Adekunie (2016) have indicated, the division of labor is becoming blurred. Many men have left the land to work in the towns or neighboring countries. Also, HIV related diseases and deaths have had a major effect on the agricultural labor force. As a result, women sometimes comprise up to $80 \%$ of the adult rural population and are made to take on jobs that were traditionally done by men; farming is one focus in this paper.

\subsection{The Study: The Research Question}

The picture of Burundi painted by Jenicek and Grofova (2015) is grim. They described an impoverished, over-populated country with limited resources that cannot overcome its hunger problem in the near future. They noted that in 2005 , the real per capita GNP dropped to $\$ 105$, which meant that 
if that trend persisted, Burundi would need 225 years to reduce its poverty by half. Against that backdrop, this study looks at hunger in Burundi and attempts to identify the factors that are related to hunger in present day Burundi. As the title of this paper suggests, the search will be to determine whether there are any rays of hope for the hunger problem in Burundi, or is hunger destined to be perpetual. Several known rays of hope are currently in the process of development and will be covered below in the Discussion section.

\section{Method}

The Data: This study's Data Source is the Afrobarometer project. As recently described by Fry (2017), it is a collaborative research effort formed in 1999 when three independent research projects merged; there were Michigan State University, the Institute for Democracy in South Africa and the Center for Democratic Development. The Project's objectives are as follows: 1) to produce scientifically reliable data on public opinion in sub-Saharan Africa; 2) to strengthen institutional capacity for survey research in Africa; and 3) to broadly disseminate and apply survey results. In 2000, Afrobarometer joined other regional barometers to form the Global Barometer Network; the following year, Afrobarometer completed the Round 1 survey. The project started with 12 countries in Round 1, and by 2016 Round 6 was completed, in 36 African countries. The project uses a standardized questionnaire, with new questions or country specific questions added by round.

The individual country is the unit of analysis and sampling goal is to create national probability samples which represent cross sections of adult citizens, 18 years and older, for each country. Sampling sizes are set at either 1,200 or 2,400 respondents, depending upon the country's population size. The sampling procedures used in all of the Afrobarometer surveys are explained in detail in Bratton, Mattes and Gyimah-Boadi (2005).

\subsection{The Dependent Variable: Hunger}

The study's questionnaire included what is called The Lived Poverty Index used in the Afrobarometer studies which was adopted from Mattes (2003). One of the five questions in the Index asked "over the past year, how often, if ever, have you or anyone in your family gone without enough food to eat". Fixed responses to this question were: never, just once or twice, several times, many times, always. These responses were coded as follows: Never $=1$, just once or twice $=2$ and many times and always $=$ 3. These categories provide the basis for the ordered logistical analysis presented in the Results section.

\subsection{The Independent Variables}

The Afrobarometer questionnaire does not ask respondents to report their income. As Bratton (2008) indicated, this is because many citizens in poor countries operate in informal markets where cash transactions, including income, are unrecorded and difficult to measure. Instead, this research used what is called an Asset-based Wealth Index, a summed index created from four questions that ask about household assets. The survey asked respondents: "Which of these things do you personally own: A radio? A television? A motor vehicle, car or motorcycle? a cell phone?" Responses to these questions 
were coded as binary. Either $(0=$ don't own; $1=$ own $)$, and these responses were used to create a summed index for this study.

Other control variables are listed in Table 1 and were measured by a single item, like age, and others were collapsed into fewer categories. Race and religion are not included in Table 1 because over 99 percent of the respondents were classified as Black Africans and over 95 percent of the respondents reported that they were Christians. Education was reduced to four categories from nine by combining no school, informal only and then creating primary, high school. And post secondary categories. Respondents were asked a series of work related questions, like their employment status. Respondents were also asked to identify the most important problems faced by the country that the government should address. Respondents were provided with two hypothetical questions which asked what would be their top and second priorities for additional investment if the country could increase spending. Fixed responses were provided, which included education, infrastructure, security, healthcare, agriculture and development, energy supply or none of the above. The responses to these questions are also listed in Table 1. Note that race and religion are not included in Table 1 because over 99 percent of the respondents were classified as Black Africans and over 95 percent of the respondents reported that they were Christians.

Table 1. Social and Demographic Characteristics of the Burundi Sample $(\mathbf{N}=1,200)$

\begin{tabular}{|c|c|}
\hline Variable & $\mathbf{N}(\%)$ \\
\hline \multicolumn{2}{|l|}{ Gender } \\
\hline Male & $600(50)$ \\
\hline Female & $600(50)$ \\
\hline \multicolumn{2}{|l|}{ Education } \\
\hline No formal/informal schooling & $456(38)$ \\
\hline Some/Primary school completed & $540(45)$ \\
\hline Some/completed high school & $156(13)$ \\
\hline postsecondary/college/graduation & $46(4)$ \\
\hline \multicolumn{2}{|l|}{ Employment } \\
\hline Unemployed & $1,038(87)$ \\
\hline Employed part time & $38(3)$ \\
\hline Employed full time & $124(10)$ \\
\hline \multicolumn{2}{|l|}{ Residence } \\
\hline Urban & $168(14)$ \\
\hline Rural & $1,032(86)$ \\
\hline \multicolumn{2}{|l|}{ Age } \\
\hline 18 through 29 & $402(34)$ \\
\hline
\end{tabular}


30 through 49

50 and over

\section{Agricultural worker/occupation}

Yes

No

\section{Asset-based Wealth}

None of these

Radio

Radio and TV

Radio, TV and motor vehicle (car or motorcycle)
$356(30)$

434 (36)

$364(30)$

$93(8)$

Table 1, shows this Burundi sample was relatively young, with 70 percent under the age of 50 . Forty-five percent of the respondents have some attendance or have completed primary school, while 38 percent have not attended school or have received informal education only. Thirteen percent attended some or completed high school and 4 percent of the sample have post-secondary education. Only 10 percent of the sample was employed and 87 percent were unemployed. The sample was overwhelmingly rural, 86 percent and 70 percent listed their occupations as in agriculture, farming, forestry or fishing. In terms of the assets they owned, 38 percent indicated they only owned a radio, while 34 percent indicated they did not own any of the assets on the list. Eight percent of the sample owned a radio, TV and a vehicle.

\section{Results}

The next task in the analysis was to identify the respondents self-reported level of hunger, how often they go with out basic necerssities (food) and perceptions of problems the government should address or where the government should direct funds if money was available. The responses to those items appear in Table 2.

Table 2. Self-Reported Hunger, Lack of Access to Basic Necessities (Food), and Perceptions of Governmental Priorities and Possible Investment $(\mathbf{N}=\mathbf{1 , 2 0 0})$

\begin{tabular}{ll}
\hline Variable & $\mathbf{N}(\boldsymbol{\%})$ \\
\hline Hunger & \\
Never & $348(29)$ \\
Sometimes & $581(48)$ \\
Always & $271(23)$ \\
Basic necessities (food) & \\
About once every two to three months & $42(4)$ \\
\hline
\end{tabular}


Once a month

$105(9)$

Two or three times a month

165 (14)

Once a week

Several times a week

Everyday

Government ensuring everyone has enough to eat

Badly

Well

$216(18)$

Respondent selections of the priorities government should address

Poverty/Food Shortage/famine

Farming and Agriculture

Corruption

Health

Crime

Water supply

Unemployment

Management of the economy

AIDS

Votes for Top Priority for additional government investment

Agricultural development

Healthcare

600

Education

440

Infrastructure

Security

Energy supply 182

None of the above

20

Table 2 reveals that 71 percent of this Burundi sample report some degree of hunger, with 23 percent indicating they are always hungry. Thirty-eight percent reported being hungry several times a week. And 13 percent reported being hungry every day. Poverty and destitution was the top choice as the priority the government should address, 15 percent, followed by food shortage, 9 percent, and farming and agriculture, 8 percent. Agricultural development received the most votes regarding where the government should invest funds if money was available. Healthcare was second, followed by education and infrastructure.

The next task in the analysis was to cross-tabulate some of the study's independent variables by hunger. These results appear in Table 3 . 
Table 3. Cross-Tabulation Hunger and Selected Independent Variables $(N=1,200)$

\begin{tabular}{|c|c|c|c|c|c|}
\hline \multicolumn{6}{|c|}{ Hunger level } \\
\hline \multirow[b]{2}{*}{ Variable } & None & Some & a lot & Total & $\mathbf{P}$ \\
\hline & $\mathbf{N}(\%)$ & $\mathbf{N}(\%)$ & $\mathbf{N}(\%)$ & & \\
\hline \multicolumn{6}{|l|}{ Gender } \\
\hline Male & $180(30)$ & $306(51)$ & $114(19)$ & 600 & .01 \\
\hline Female & $168(28)$ & $275(46)$ & $157(26)$ & 600 & \\
\hline \multicolumn{6}{|l|}{ Education } \\
\hline No formal/informal only & $90(20)$ & $219(48)$ & $147(32)$ & 456 & .000 \\
\hline Some/Primary school completed & $150(28)$ & $283(52)$ & $107(20)$ & 540 & \\
\hline Some/completed high school & $72(46)$ & $71(45)$ & $15(9)$ & 158 & \\
\hline Postsecondary/college/graduation & $36(78)$ & $8(17)$ & $2(4)$ & 46 & \\
\hline \multicolumn{6}{|l|}{ Employment } \\
\hline Unemployed & $288(28)$ & $504(49)$ & $246(24)$ & 1,038 & .04 \\
\hline Employed part time & $17(45)$ & $15(39)$ & $6(16)$ & 38 & \\
\hline Employed full time & $43(35)$ & $62(50)$ & $19(15)$ & 124 & \\
\hline \multicolumn{6}{|l|}{ Residence } \\
\hline Urban & $83(49)$ & $61(36)$ & $24(14)$ & 168 & .000 \\
\hline Rural & $265(26)$ & $520(50)$ & $247(24)$ & 1,032 & \\
\hline \multicolumn{6}{|l|}{ Agricultural worker/occupation } \\
\hline Yes & $191(23)$ & $397(49)$ & $230(28)$ & 518 & .000 \\
\hline No & $145(41)$ & $175(49)$ & $36(10)$ & 356 & \\
\hline \multicolumn{6}{|l|}{ Asset-based Wealth } \\
\hline None of these & $87(21)$ & $190(47)$ & $130(32)$ & 407 & .000 \\
\hline Radio & $124(27)$ & $229(50)$ & $105(23)$ & 458 & \\
\hline Radio and TV & $71(29)$ & $141(59)$ & $29(12)$ & 241 & \\
\hline Radio, TV and motor vehicle & $66(71)$ & $20(22)$ & $7(9)$ & 93 & \\
\hline \multicolumn{6}{|l|}{ Age } \\
\hline 18 through 29 & $118(29)$ & $196(49)$ & $88(22)$ & 402 & .71 \\
\hline 30 thru 49 & $134(31)$ & $203(47)$ & $97(22)$ & 434 & \\
\hline 50 and over & $96(26)$ & $182(50)$ & $86(24)$ & 364 & \\
\hline \multicolumn{6}{|c|}{ Government ensuring everyone has enough to eat } \\
\hline Badly & $282(29)$ & $475(49)$ & $214(22)$ & 971 & .65 \\
\hline Good & $64(30)$ & 99 (46) & $53(24)$ & 216 & \\
\hline
\end{tabular}

Table 3 shows that most of the variables included in Table 3 were statistically significant. The two 
exceptions were age and respondent perceptions regarding whether the government was ensuring that people had enough to eat. Some other variables included in Table 3 were highly significant. These included education, residence, agricultural work as an occupation and the asset based wealth index. All at $\mathrm{p}=.000$. Gender at $\mathrm{p}=.01$ and employment status, $\mathrm{p}=.04$, were also significant, but to a lesser degree.

The final task in the analysis was to conduct an ordered logistical regression analysis to determine which variables predicted hunger in Burundi. An ordered logistical model was appropriate because the study had a categorical dependent variable. The statistical program used for all of the analysis presented in this paper was Stata, and Long and Freese (2006) discuss the use of regression models for categorical dependent variables when using Stata. The results of this study's ordered logistical analysis appear in Table 4.

Table 4. Logistic Regression with Self-Reported Hunger as the Dependent Variable

\begin{tabular}{lllll}
\hline Variable & Coefficient & Standard Error & Z & P \\
\hline urban-rural & -.13 & .21 & .61 & .54 \\
Gender & & .12 & 1.31 & .19 \\
Employment status & .06 & .19 & .59 & .55 \\
Total assets & -.29 & .11 & -2.63 & .01 \\
Education & -.42 & .10 & 4.27 & .00 \\
Agriculture worker & .48 & .15 & 3.11 & .00 \\
Age & -.10 & .08 & -1.28 & .20 \\
Government doing enough & .64 & .28 & 2.27 & .02 \\
Invest agriculture & .04 & .03 & 1.50 & .13 \\
Number of observations $=1,097$ & & & & \\
LR chi2(12) $=164.29$ & & & & \\
Prob > chi2 = 0.0000 & & & & \\
Pseudo R2 = 0.07 & & & & \\
\hline
\end{tabular}

Table 4 shows that 4 variables reached significance in the regression equation. In order of their strength, these were education, agricultural worker as the respondent's occupation, the asset based wealth indicator, and whether respondents thought the government was ensuring that people had enough to eat. Perhaps what is most interesting are those variables that were expected to be significant and were not. These include gender and the rural-urban dimension, which the literature suggested were significant predictors of hunger. Perhaps this can be explained by the significance of agriculture as an occupation. Another significant variable identified above and not included in the regression analysis was the basic necessity indicator, and that was because the items multicollinearity with hunger. 


\section{Discussion}

Another issue which disappeared in the regression analysis was the need to invest in agriculture, which appears to be a major solution to the world food and hunger crisis found in the recent literature (Fan \& Rosegrant, 2016). The thinking is that increased agricultural growth will play a major role in addressing the world food crisis and the major stumbling block will be the cost.

There are grass roots approaches to the hunger problem in Burundi noted in the literature and one will be mentioned here. This may be defined as taking advantage of what already exists in the environment. The example is provided by Akinnifesi et al. (2006), who noted that among the consequences of most countries in Southern Africa experiencing acute malnutrition, food insecurity, and poverty among both rural and urban populations is deforestation and loss of biodiversity. It has been recognized what are known as the Miombo woodlands are in danger, an area which includes Southern Burundi. This forest area is known to have over 75 Indigenous Fruit Trees (IFTs), which bear edible fruits. These fruits are rich in minerals and vitamins, can be sold for cash income and are an important food source during emergencies. Akinnifesi et al. provide an overview of some efforts to domesticate the IFTs identified by farmers and users as priority species, which is as an important step to providing opportunities for resource-poor farmers to cultivate and generate income from the sale of fresh and processed products. The approach used involves four basic steps: 1) identification of priority species by communities and other users, 2) participatory selection of superior trees and naming them in situ, 3) propogation and cultivation of trees as fruit orchards, and 4) dissemination and adoption. To this point, over 5000 farmers in four countries are involved in on-farm testing of IFTs in the field and homesteads.

This example points to the need to create an enabling environment, and demonstrates that policy reforms and market development will be necessary to achieve socioeconomic empowerment of the resource poor farmers in the region through domestication, utilization and commercialization of fruits and other agricultural commodities, which in turn stresses the need for product development research, private sector involvement and strong policy support, in order for other similar projects to have tangible impact.

As far as can be determined, this is the only published study that has assessed hunger in Burundi through individual level survey methods, yet, the results presented here are consistent with other assessments of hunger in Burundi. For example, the Borgenproject (2014) reported that the rates of malnutrition have increased and Burundi is only one of four nations that has seen an increase in GHI (Global Hunger Index) from 1990 to 2016, indicating a worsening of the food situation in the country. The picture presented here and elsewhere suggest that the prospects for the future of hunger looks dismal for Burundi. At first glance, the fact that education was the first predictor to emerge from the regression analysis might seem favorable. In fact, Burundi has been identified as the African Country least able to retain its top talent (Mail Guardian, 2015). This comes about because the pursuit of opportunities outside the country is called a feature of working life, and Burundi was ranked number one in terms of the country where the best and brightest leave for opportunities in other countries and at 
the bottom of the list of African Countries able to attract top talent. The country cannot create more farm land, and the remaining forest land must be and will be protected; the example provided by the Miombo woodlands makes that case.

In conclusion, the answer to the question which generated this paper is that hunger will be or remain perpetual in Burundi into the foreseeable future. Seventy-one percent of the respondents to this survey reported some degree of hunger, with about one-fourth, 23 percent, reporting that they are hungry all the time. About 87 percent of the respondents in this study were unemployed and 86 percent listed some form of agriculture as their occupation. The surprising finding was that, while significant at the bivariate level, gender was not significant in the regression analysis, suggesting that everyone is hungry in Burundi, women and men, and this study suggests there is no apparent improvement on the horizon.

\section{References}

Adebayo, S. A., \& Adekunle, O. A. (2016). Socio-economic status of women in group membership in selected areas of Kwara State, Nigeria. Agrosearch, 16(1), 57-64. https://doi.org/10.4314/agrosh.v16i1.5

Akinnifesi, F., Kwesiga, J., Mhango, T., Chilanga, A., Mkonda, C., \& Kadzere, K. I. (2006). Towards the development of miombo fruit trees as commercial tree crops in southern Africa. Forests, Trees and Livelihoods, 16(1), 103-121. https://doi.org/10.1080/14728028.2006.9752548

Borgenproject. (2014). Malnutrition in Burundi. Retrieved from https://www.borgenproject.org

Bratton, M., Robert, B. M., \& Emmanuel, G.-B. (2005). Public opinion, democracy, and market reform in Africa. Cambridge University Press.

Clover, J. (2003). Food security in sub-Saharan Africa: Feature. African security review, 12(1), 5-15. https://doi.org/10.1080/10246029.2003.9627566

Fan, S., \& Rosegrant, M. (2016). Investing in agriculture to overcome the world food crisis and reduce poverty and hunger. Washington, DC: IFPRI (International Food Policy Research Institute). Retrieved from https://www.vtechworks.lib.vt.edu

Fauk, N., Mwakinyali, S., Sukma, P., \& Mwanri, L. (2017). Understanding the strategies employed to cope with increased numbers of AIDS-orphaned children in families in rural settings: A case of Mbeya Rural District, Tanzania. Infectious Diseases of Poverty, 6(1). https://doi.org/10.1186/s40249-016-0233-7

Fry, L. (2017). The Value of Publicly Available Data Sets for Social Science Research and Evaluation. International Journal of Current Advanced Research, 6(1), 1777-1783.

Jeníček, V., \& Grofová, S. (2015). Least developed countries-the case of Burundi. Agric. Econ.-Czech, 61, 234-247. https://doi.org/10.17221/48/2014-AGRICECON

Long, J., \& Freese, J. (2006). Regression models for categorical dependent variables using Stata. Stata press.

Mail guardian. (2015). Brain drain in Africa: Burundi least able to retain its top talent, Rwanda, Kenya 
top Jammeh's Gambia surprises. Retrieved from http:://www.mgafrica.com/article.2015-08-28

Mattes, R., \& Gyimah-Boadi, E. (2005). Public Opinion, Democracy, and Market Reform in Africa. Cambridge: Cambridge University Press.

Mattes, R., Bratton, M. \& Davids, Y. (2003). Poverty, Survival, and Democracy in Southern Africa. Afrobarometer Working Paper.

Muthayya, S., Jee, H., Sugimoto, J. Roos, F., Kraemer, H., \& Black, R. (2013). The global hidden hunger indices and maps: An advocacy tool for action. PLoS One, 8(6), e67860. https://doi.org/10.1371/journal.pone.0067860

Notes, Hunger. (2011). World hunger and poverty facts and statistics. Washington, DC: World Hunger Education Service.

Poor People and Democratic Citizenship in Africa. (2008). In A. Krishna (Ed.), Poverty, Participation and Democracy. New York: Cambridge University.

Sanchez, P. A., \& Swaminathan, M. S. (2005). Hunger in Africa: The link between unhealthy people and unhealthy soils. The Lancet, 365(9457), 442. https://doi.org/10.1016/S0140-6736(05)70241-5

Shisanya, S., \& Mafongoya, P. (2016). Adaptation to climate change and the impacts on household food security among rural farmers in uMzinyathi District of Kwazulu-Natal, South Africa. Food Security, 8(3), 597-608. https://doi.org/10.1007/s12571-016-0569-7

The material and political bases of lived poverty in Africa: Insights from the Afrobarometer. (2008). In Barometers of Quality of Life Around the Globe (pp. 161-185). Springer Netherlands.

Tilman, D., \& Clark. (2015). Food, Agriculture \& the environment: Can we feed the world \& save the Earth? Daedalus, 144(4), 8-23. https://doi.org/10.1162/DAED_a_00350

World Health Rankings: Burundi. (2013). Retrieved from http://www.worldlife expectancy.com/Burundi

$\begin{array}{llll}\text { Worldifeexpectancy, } & \text { Burundi. } & \text { (n.d.). } & \text { Retrieved }\end{array}$ http://www.worldlifeexpectancy.com/burundi-life-expectancy 